\title{
PERAN KEPERCAYAAN MEREK MEMEDIASI ELECTRONIC WORD OF MOUTH TERHADAP KEPUTUSAN PEMBELIAN
}

\author{
Nency Silviana Dewi ${ }^{1}$ \\ Ida Bagus Sudiksa ${ }^{2}$ \\ ${ }^{1,2}$ Fakultas Ekonomi dan Bisnis Universitas Udayana (Unud), Bali, Indonesia \\ email:nencydewi25@gmail.com
}

\begin{abstract}
ABSTRAK
Tujuan dari penelitian ini adalah untuk menguji pengaruh eWOMterhadap keputusan pembelian melalui kepercayaan merek pada konsumen produk Maybelline di Kota Denpasar. Variabel yang diteliti dalam penelitian ini adalah variabel eWOM, kepercayaan merek, dan keputusan pembelian. Ukuran sampel yang diambil penyebaran sebanyak 100 responden. Metode pengumpulan data dalam penelitian ini melalui kuesioner. Teknik analisis yang digunakan adalah analisis jalur dengan uji asumsi klasik dan uji sobel. Berdasarkan hasil analisis, ditemukan bahwa eWOM berpengaruh secara positif dan signifikan terhadap kepercayaan merek, eWOMberpengaruh secara positif dan signifikan terhadap keputusan pembelian, kepercayaan merekberpengaruh secara positif dan signifikan terhadap keputusan pembelian, serta kepercayaan merek bereperan signifikan memediasi eWOM terhadap keputusan pembelian produk Maybelline di Kota Denpasar. eWOM yang positif merupakan salah satu upaya dalam meningkatkan kepercayaan merek. Mempertahankan kepercayaan merek memegang peranan yang penting dalam terciptanya keputusan pembelian produk. Melalui eWOM yang positif, konsumen terdorong untuk segera melakukan keputusan pembelian.
\end{abstract}

Kata Kunci:electronic word of mouth (eWOM), kepercayaan merek, keputusan

\begin{abstract}
The purpose of this study was to examine the effect of eWOM on purchasing decisions through brand trust in Maybelline product consumers in Denpasar City. The variables examined in this study were eWOM variables, brand trust, and purchasing decisions. The sample size taken is 100 respondents. The method of collecting data in this study through a questionnaire. The analysis technique used is path analysis with classic assumption test and sobel test. Based on the results of the analysis, it was found that eWOM had a positive and significant effect on brand trust, eWOM had a positive and significant effect on purchasing decisions, brand trust positively and significantly influenced purchasing decisions, and brand trust significantly mediated eWOM on Maybelline product purchasing decisions in Denpasar City. Positive eWOM is an effort to increase brand trust. Maintaining brand trust plays an important role in creating product purchasing decisions. Through positive eWOM, consumers are encouraged to immediately make purchasing decisions.
\end{abstract}

Keywords: electronic word of mouth (eWOM), brand trust, decision 


\section{PENDAHULUAN}

Dewasa ini persaingan bisnis kian hari semakin kompetitif. Hal ini dikarenakan terjadinya globalisasi dan digitalisasi. Perkembangan dalam bidang teknologi informasi yang sangat pesat memiliki dampak yang luas pada lingkungan bisnis (Suprapti, 2010). Dunia bisnis semakin dinamis dengan adanya perkembangan teknologi, di mana perusahaan dituntut untuk bergerak mengikuti selera konsumen dan menyediakan beragam produk dengan mengikuti perkembangan teknologi. Salah satu manfaat positif yang diperoleh dengan adanya perkembangan teknologi adalah kemudahaan dalam ekspor-impor barang.

Produk-produk baru diciptakan kemudian akan di ekspor ke berbagai negara, diantaranya adalah negara Indonesia yang menjadi tujuan negara asing untuk mengekspor produk-produknya. Hal ini membuat konsumen tertarik karena dengan adanya penawaran yang sangat beragam, harga bersaing, dan cara-cara promosi melalui media sosial. Industri kosmetik dunia merupakan salah satu yang menawarkan berbagai pilihan merek dan kemudian akan diekspor ke berbagai negara. Harga produk kosmetik yang ditawarkan sangat beragam, mulai dari produk kosmetik dengan harga yang murah hingga mahal. Berbagai macam merek yang ada akan menentukan biaya yang harus dikeluarkan oleh konsumen untuk menikmati kualitas produk yang sesuai.

Preferensi merek kosmetik konsumen Indonesia pada tahun 2016 menunjukkan bahwa sebesar $48 \%$ konsumen Indonesia menyukai kosmetik merek global dan 36\% memilih kosmetik merek lokal, sementara sebesar 16\% sisanya tidak memiliki preferensi apapun (Databoks.katadata.co.id., 2016). Hal ini 
menunjukkan bahwa konsumen Indonesia cenderung lebih memilih membeli produk kosmetik buatan luar negeri daripada produk lokal. Permintaan kosmetik impor Indonesia terus meningkat seiring dengan gaya kehidupan yang modern dan kebutuhan akan merek kosmetik premium dari konsumen kelas menengah ke atas di Indonesia.

Salah satu perusahaan kosmetik luar negeri yang sukses dalam memasuki pasar Indonesia adalah Maybelline New York. Perusahaan global ini memproduksi kosmetik internasional yang didirikan pada tahun 1915 oleh Thomas Lyle Williams di New York, Amerika Serikat. Produk yang dihasilkan oleh perusahaan Maybelline adalah berkonsentrasi pada riasawan wajah. Macammacam riasan wajah yang diproduksi diantaranya adalah foundation, bedak, blush on, eye shadow, eye liner, lip gloss, lips treatment, lipstick, make up remover, maskara, dan pensil alis.

Tabel 1.

Top Brand Index Kategori Perawatan Pribadi

\begin{tabular}{|c|c|c|c|c|c|c|c|c|c|}
\hline \multirow[b]{2}{*}{ Merek } & \multicolumn{3}{|c|}{ TBI Maskara } & \multirow[b]{2}{*}{ Top } & \multirow[b]{2}{*}{ Merek } & \multicolumn{3}{|c|}{ TBI Lip Gloss } & \multirow[b]{2}{*}{ Top } \\
\hline & $\begin{array}{c}2016 \\
(\%) \\
\end{array}$ & $\begin{array}{c}2017 \\
(\%) \\
\end{array}$ & $\begin{array}{c}2018 \\
(\%) \\
\end{array}$ & & & $\begin{array}{c}2016 \\
(\%)\end{array}$ & $\begin{array}{l}2017 \\
(\%) \\
\end{array}$ & $\begin{array}{c}2018 \\
(\%) \\
\end{array}$ & \\
\hline Maybelline & 25,3 & 26,8 & 22,0 & Top & Wardah & 13,7 & 23,1 & 31,8 & Top \\
\hline Wardah & - & 12,2 & 19,0 & Top & Revlon & 12,9 & - & 12,0 & Top \\
\hline Oriflame & 13,6 & - & 11,5 & Top & Maybelline & 12,5 & 10,8 & 10,9 & Top \\
\hline $\mathrm{QL}$ & 10,0 & - & - & Top & & & & & \\
\hline
\end{tabular}

Produk maskara dan lip gloss dari Maybelline konsisten menjadi Top Brand di Indonesia selama 3 tahun berturut-turut mulai dari tahun 2016 hingga tahun 2018. Nilai Top Brand Index (TBI) produk maskara dan lip gloss dari Maybelline terlihat berfluktuasi, hal ini disebabkan munculnya pesaing-pesaing baru. Menempati posisi Top Brand selama 3 tahun berurut-turut, hal ini menyatakan 
bahwa produk Maybelline menjadi merek kosmetik yang unggul dan digemari oleh masyarakat Indonesia sehingga menimbulkan positif Word of Mouth (WOM) terhadap produk kosmetik Maybelline tersebut.

WOM terbukti berdampak tinggi pada perilaku konsumen, dan para pemasar menyepakati bahwa kekuatan WOM dapat mengubah komunikasi pemasaran di masa depan (Sirma, 2009 dan Sweeney, 2014). Kemajuan teknologi yang berkembang pesat mengakibatkan terciptanya sebuah paradigma baru dalam komunikasi, yang sebelumnya menggunakan WOM kini menjadi Electronic Word of Mouth (eWOM) (Elaziz et al., 2015). eWOM berbeda dengan WOM tradisional karena sumber informasi memiliki sedikit atau bahkan tidak ada hubungan sebelumnya dengan pencari informasi (Xia dan Bechwati, 2008). Sedangkan menurut Syafaruddin et al. (2016) perbedaan antara WOM dengan eWOM dapat dibedakan berdasarkan pada media yang digunakan, penggunaan WOM tradisional lebih bersifat face-to-face (tatap muka) sedangkan pada komunikasi eWOM bersifat secara online melalui cyberspace.

Menurut Litvin et al. (2008) eWOM adalah bentuk dari komunikasi non formal yang diarahkan pada konsumen melalui sebuah teknologi berbasis internet terkait dengan karakteristik atau penggunaan barang dan jasa tertentu. Komunikasi eWOM dilakukan melalui media online seperti email, blog, chat room, twitter, facebook dan berbagai jenis media sosial lainnya yang dapat menimbulkan interaksi antara konsumen satu dengan konsumen lainnya untuk berbagi pengalaman dalam bentuk opini dan pengetahuan. (Kamtarin, 2010 dan Pedersen et al., 2014). 
Arwiedya dan Sugiarto (2011) mengemukakan bahwa eWOM adalah proses WOM dengan menggunakan media internet atau web, di mana dalam media promosi yang berpengaruh terhadap keputusan pembelian, salah satunya adalah eWOM. Internet telah mengubah cara konsumen dalam mencari barang dan jasa, saat ini banyak orang hanya mengetik apa yang mereka cari ke mesin pencarian dan apa yang mereka temukan akan memiliki pengaruh pada keputusan pembelian mereka (Cantallops dan Salvi, 2014). Konsumen akan terlebih dahulu menjelajahi web untuk membaca komentar dan ulasan online mengenai produk atau jasa yang mereka minati untuk membantu dalam membuat keputusan pembelian (Almana dan Mirza, 2013). eWOM akan menyebar lebih cepat dan lebih luas sehingga memiliki dampak yang lebih kuat pada proses pembuatan keputusan konsumen (Pourabedin dan Migin, 2015). Adanya aktivitas eWOM, konsumen akan mendapatkan tingkat transparansi pasar yang tinggi, dengan kata lain konsumen memiliki peran aktif yang lebih tinggi dalam siklus rantai nilai sehingga mampu memengaruhi produk dan harga berdasarkan preferensi individu (Park dan Kim,2008).

Melalui rekomendasi dari konsumen lain biasanya dianggap lebih dipercaya daripada kegiatan promosi yang berasal dari perusahaan, hal tersebut akan berpengaruh terhadap keputusan orang lain untuk menggunakan ataupun menghindari suatu jasa (Lovelock et al., 2010:216). Keputusan adalah suatu hasil dari proses memilih dari beberapa pilihan atau alternatif yang tersedia (Suprapti 2010:264). Menurut Kotler dan Armstrong (2016:185), keputusan pembelian adalah suatu tahap proses keputusan di mana konsumen secara aktual melakukan 
pembelian produk. Hasil penelitian Adeliasari et al. (2014) dan Akram dan Wibowo (2016) menyatakan bahwa eWOM berpengaruh secara signifikan dan positif terhadap keputusan pembelian. Hal ini bertentangan dengan hasil penelitian yang dilakukakn oleh Wijaya dan Paramita (2014) yang menunjukkan eWOM tidak berpengaruh secara signifikan terhadap keputusan pembelian.

Referensi eWOM yang positif merupakan salah satu upaya untuk membangun kepercayaan terhadap merek (Jansen et al., 2009), yang artinya adalah eWOM sangat menentukan kepercayaan terhadap suatu merek. Kepercayaan terhadap suatu merek memiliki pengaruh yang sangat besar terhadap keberlangsungan merek tersebut, karena jika sebuah merek sudah tidak dipercayai lagi di mata konsumen maka produk dengan merek tersebut akan sulit untuk berkembang di pasar. Hal sebaliknya, apabila merek tersebut dipercayai oleh konsumen, maka produk dengan merek tersebut akan terus berkembang di pasar. Kepercayaan terhadap merek memegang peranan yang penting dalam terciptanya keputusan konsumen terhadap suatu merek tertentu.

Kepercayaan merek (brand trust) akan menentukan pembelian konsumen terhadap merek dan kepercayaan akan berpotensi menciptakan hubunganhubungan yang bernilai tinggi (Wulandari dan Nurcahya, 2015). Keprcayaan merek berpengaruh positif dan signifikan terhadap keputusan pembelian (Mamahit et al., 2015 dan Adiwidjaja dan Taringan, 2017). Hal ini bertentangan dengan hasil penelitian Nofianti (2014) yang menyatakan bahwa kepercayaan merek tidak memiliki pengaruh terhadap keputusan pembelian. 
Hasil pra survey yang dilakukan oleh peneliti kepada 15 responden yang merupakan konsumen produk Maybelline di Kota Denpasar, terdapat 11 orang menyatakan hal positif mengenai produk kosmetik dari Maybelline, sedangkan sisanya sebanyak 4 orang menyatakan hal yang negatif mengenai produk kosmetik Maybelline. Hal positif yang dinyatakan karena konsumen merasakan bahwa produk kosmetik dari Maybelline memiliki kualitas yang unggul dan cocok dengan kulit atau wajah ketika digunakan. Sedangkan hal negatif yang dinyatakan karena konsumen merasa produk kosmetik dari Maybelline tergolong cukup mahal dan masih banyak produk lokal yang tidak kalah bagus kualitasnya dibandingkan produk Maybelline.

Terdapat merek kosmetik global unggul yaitu Maybelline, sehingga menimbulkan positif eWOM melalui kepercayaan merek dan adanya research gap yang menarik untuk diteliti lebih lanjut mengenai peran kepercayaan merek memediasi eWOM terhadap keputusan pembelian, studi pada konsumen produk Maybelline di Kota Denpasar.

Adapun tujuan penelitian yang ingin dicapai dari penelitian ini adalah sebagai berikut: 1) Untuk menjelaskan pengaruh eWOM terhadap kepercayaan merek produk Maybelline di Kota Denpasar, 2) Untuk menjelaskan pengaruh eWOM terhadap keputusan pembelian produk Maybelline di Kota Denpasar, 3) Untuk menjelaskan pengaruh kepercayaan merek terhadap keputusan pembelian produk Maybelline di Kota Denpasar, 4) Untuk menjelaskanperan kepercayaan merek mediasi eWOM terhadap keputusan pembelian produk Maybelline di Kota Denpasar. 
Hasil dari penelitian ini diharapkan dapat memberikan sumbangan dan bukti empiris mengenai peran kepercayaan merek memediasi eWOM terhadap keputusan pembelian produk Maybelline serta mampu memberikan masukan dan bahan pertimbangan sehingga dapat dijadikan acuan serta referensi perusahaan Maybelline untuk membangun strategi pemasaran yang efektif untuk meningkatkan penjualan.

Menurut Litvin et al. (2008), eWOM adalah bentuk dari komunikasi non formal yang diarahkan pada konsumen melalui sebuah teknologi berbasis internet terkait dengan karakteristik atau penggunaan barang dan jasa tertentu. Arwiedya dan Sugiarto (2011) mengemukakan bahwa eWOM adalah proses WOM dengan menggunakan media internet atau web, di mana dalam media promosi yang berpengaruh terhadap keputusan pembelian salah satunya adalah eWOM.Sejak munculnya teknologi informasi dan internet, WOM telah memperoleh beberapa nama baru yaitu eWOM (Goyette et al., 2010).

Chu dan Kim (2011) menyatakan bahwa eWOM dalam situs jejaring sosial terjadi ketika konsumen menyediakan atau mencari saran yang terkait mengenai suatu produk melalui aplikasi dari situs-situs online. Pemaparan sukarela terhadap informasi merek dalam situs jejaring sosial adalah penting karena konsumen mencari cara untuk berinteraksi dengan merek dan konsumen lain, yang memungkinkan eWOM menjadi bersifat interaktif.

Menurut Kumar (2008:69), kepercayan merek adalah kerelaan individu mempercayai kemampuan merek untuk memuaskan kebutuhannya. Kepercayaan merek menyiratkan bahwa konsumen memiliki harapan positif dan percaya pada 
merek dan memainkan peran sebagai fasilitator dalam proses pembelian (Luk dan Yip, 2008).

Kredibilitas mencerminkan kejujuran dan status merek dalam kaitannya dengan tuntutan produk atau layanan yang disampaikan dalam iklan, kemasan, atau bentuk komunikasi merek lainnya, termasuk interaksi pribadi. Dimensi ini juga mencerminkan sejauh mana merek yang dianggap tulus dan wajar dalam berurusan dengan pelanggannya, menunjukkan kepedulian terhadap pelanggannya, dan nilai-nilai yang digambarkan atau diterima dari merek (dan pemilik merek) mencerminkan nilai-nilai yang dimiliki konsumen. Dimensi kredibilitas juga berhubungan dengan baik atau buruknya karakter dari merek. Selain itu, dimensi ini juga mengukur sejauh mana merek dipercaya sebagai merek yang kompeten atau ahli di bidangnya. Reputasi merupakan elemen kunci dalam dimensi ini.

Keputusan adalah suatu hasil dari proses memilih dari beberapa pilihan atau alternatif yang tersedia (Suprapti, 2010:264). Dalam proses pengambilan keputusan, konsumen membutuhkan informasi dan akan melakukan upaya-upaya tertentu untuk memperoleh informasi itu. Tiap keputusan membutuhkan kontinum mulai dari yang tertinggi sampai yang terendah. Pengambilan keputusan dapat dibedakan menjadi tiga tingkatan berdasarkan kontinum pencarian informasi, (Suprapti, 2010:265) yaitu sebagai berikut: 1) Penyelesaian Masalah Ekstensif. Pada tingkatan keputusan ini, konsumen tidak memiliki kriteria atau spesifikasi tertentu untuk mengevaluasi kategori produk atau merek-merek yang ada dalam suatu kategori produk. Dalam kondisi demikian, konsumen membutuhkan banyak 
informasi, baik tentang kategori produk maupun tentang merek-merek yang tersedia. 2) Penyelesaian Masalah Terbatas. Pada tingkatan keputusan ini, konsumen telah memiliki kriteria dasar yang akan digunakan untuk mengevaluasi suatu kategori produk dan sejumlah merek yang ada dalam kategori produk itu. Namun, mereka belum memiliki preferensi yang baik tentang merek-merek yang menjadi pilihannya. Karena itu, dibutuhkan informasi tambahan yang akan digunakan untuk membedakan merek-merek yang ada. 3) Perilaku Respon Rutin. Pada tingkatan keputusan ini, konsumen memiliki pengalaman tentang kategori produk dan memiliki kriteria yang baik untuk mengevaluasi merek-merek yang dipertimbangkan. Dalam beberapa situasi, mereka mungkin membutuhkan sedikit informasi tambahan tetapi seringkali lebih banyak mengandalkan informasi yang selama ini telah dimilikinya.

Menurut Kotler dan Armstrong (2016:185), keputusan pembelian adalah suatu tahap proses keputusan di mana konsumen secara aktual melakukan pembelian produk.

Referensi eWOM yang positif merupakan salah satu upaya untuk membangun kepercayaan terhadap merek (Jansen et al., 2009). Hasil penelitian Twinarutami dan Hermiati (2013) menyatakan eWOM berpengaruh positif dan signifikan terhadap kepercayaan merek. Selaras dengan penelitian yang dilakukan oleh Semuel dan Lianto (2014) menyatakan eWOM berpengaruh positif dan signifikan terhadap kepercayaan merek. Hasil penelitian Anggitasari dan Wijaya (2016) menyatakan bahwa eWOM berpengaruh positif dan signifikan terhadap kepercayaan merek. Hipotesis dalam penelitian ini dapat disusun sebagai berikut: 
$\mathrm{H}_{1}$ : eWOM berpengaruh positif dan signifikan terhadap kepercayaan merek.

eWOM akan menyebar lebih cepat dan lebih luas sehingga memiliki dampak yang lebih kuat pada proses pembuatan keputusan konsumen (Pourabedin dan Migin, 2015). Hasil penelitian Ekawati et al. (2014) menjelaskan bahwa ada pengaruh yang signifikansi dan positif dari eWOM terhadap keputusan pembelian. Sari et al. (2017) juga menyatakan bahwa variabel komunikasi eWOM berpengaruh positif dan signifikan terhadap keputusan pembelian. Penelitian yang dilakukan oleh Febriasari (2017) menunjukkan hasil bahwa eWOM berpengaruh positif dan signifikan terhadap proses keputusan pembelian. Hal ini bertentangan pada hasil penelitian yang dilakukan oleh Wijaya dan Paramita (2014) yang menyatakan bahwa eWOM tidak berpengaruh secara signifikan terhadap keputusan pembelian. Hipotesis dalam penelitian ini dapat disusun sebagai berikut:

$\mathrm{H}_{2}$ : eWOM berpengaruh positif dan signifikan terhadap keputusan pembelian.

Kepercayaan merek akan menentukan pembelian konsumen terhadap merek dan kepercayaan akan berpotensi menciptakan hubungan-hubungan yang bernilai tinggi (Wulandari dan Nurcahya, 2015). Hasil penelitian Wilujeng (2014) menyatakan bahwa kepercayaan merek berpengaruh positif dan signifikan terhadap keputusan pembelian. Khasanah et al. (2017) juga menyatakan bahwa kepercayaan merek berpengaruh positif dan signifikan terhadap keputusan pembelian. Hasil penelitian serupa ditemukan dalam Pratama dan Dwiarta (2017) menyatakan bahwa kepercayaan merek berpengaruh positif dan signifikan terhadap keputusan pembelian. Hal ini bertentangan dengan hasil penelitian 
Nofianti (2014) yang menyatakan bahwa kepercayaan merek tidak memiliki pengaruh terhadap keputusan pembelian. Hipotesis dalam penelitian ini dapat disusun sebagai berikut:

$\mathrm{H}_{3}$ : Kepercayaan merek berpengaruh positif dan signifikan terhadap keputusan pembelian.

eWOM memiliki efek yang kuat dalam proses membangun kepercayaan dan menyebabkan probabilitas yang lebih tinggi dalam proses pembelian (East et al., 2008). Penelitian sebelumnya yang dilakukan oleh Syafaruddin et al. (2016) menyatakan kepercayaan signifikan memediasi pengaruh eWOM terhadap keputusan pembelian. Prasad et al. (2017) menyatakan kepercayaan memiliki peran penting sebagai mediator antara eWOM terhadap keputusan pembelian. Hasil penelitian Purnamasari dan Yulianto (2018) menyatakan kepercayaan merek signifikan memediasi pengaruh eWOM terhadap keputusan pembelian. Hipotesis dalam penelitian ini dapat disusun sebagai berikut:

$\mathrm{H}_{4}$ : Kepercayaan merek signifikan memediasi pengaruh eWOM terhadap keputusan pembelian.

\section{METODE PENELITIAN}

Penelitian ini dilakukan di Kota Denpasar. Lokasi ini dipilih karena Kota Denpasar merupakan Ibu Kota Provinsi Bali dengan jumlah penduduk terbanyak diantara kota-kota lain yang ada di Bali dengan tingkat kepadatan penduduk yang sangat besar yang dipengaruhi tingkat pertumbuhan penduduk. Disamping itu Kota Denpasar adalah sebuah kota pusat pemerintahan dan perekonomian di Bali sehingga Kota Denpasar dijadikan barometer Provinsi Bali dan masyarakatnya memiliki daya beli yang lebih tinggi dibandingkan 
kota lain yang ada di Bali. Dengan demikian perilaku masyarakat Kota Denpasar mencerminkan masyarakat dengan gaya hidup yang memprioritaskan merek sebagai penunjang penampilannya..

Tabel 2.

Indikator Variabel Penelitian

\begin{tabular}{|c|c|c|c|}
\hline No. & Variabel & Indikator & Sumber \\
\hline 1. & $\begin{array}{l}\text { Electronic Word of } \\
\quad \text { Mouth }(\mathrm{X})\end{array}$ & $\begin{array}{l}\text { 1. Platform Assistance }\left(\mathrm{X}_{1}\right) \\
\text { 2. Concern for Other Consumers }\left(\mathrm{X}_{2}\right) \\
\text { 3. Economic Incentive }\left(\mathrm{X}_{3}\right) \\
\text { 4. Helping the Company }\left(\mathrm{X}_{4}\right) \\
\text { 5. Express Positive Feelings }\left(\mathrm{X}_{5}\right)\end{array}$ & Thurau et al. (2004) \\
\hline 2. & $\begin{array}{l}\text { Kepercayaan } \\
\text { Merek (M) }\end{array}$ & $\begin{array}{l}\text { 1. Brand Reliability }\left(\mathrm{M}_{1}\right) \\
\text { 2. Brand Intentions }\left(\mathrm{M}_{2}\right)\end{array}$ & Guillen (2003) \\
\hline 3. & $\begin{array}{c}\text { Keputusan } \\
\text { Pembelian (Y) }\end{array}$ & $\begin{array}{ll}\text { 1. } & \text { Kebutuhan }\left(\mathrm{Y}_{1}\right) \\
\text { 2. } & \text { Manfaat }\left(\mathrm{Y}_{2}\right) \\
\text { 3. } & \text { Rekomendasi Pembelian }\left(\mathrm{Y}_{3}\right)\end{array}$ & $\begin{array}{l}\text { Kotler dan Keller } \\
(2008: 166-189)\end{array}$ \\
\hline
\end{tabular}

Sumber:Data diolah, 2018

Populasi dalam penelitian ini adalah masyarakat yang berdomisili di Kota

Denpasar.Sampel yang digunakan dalam penelitian ini adalah konsumen yang sudah pernah membeli produk Maybelline.

Penelitian ini menggunakan teknik analisis jalur (path analysis).

Struktur 1

$M=\beta_{1} X+e_{1}$

Struktur 2

$\mathrm{Y}=\beta_{3} \mathrm{X}+\beta_{2} \mathrm{M}+\mathrm{e}_{2}$

Keterangan:

$\begin{array}{ll}\mathrm{X} & =\text { Electronic word of mouth } \\ \mathrm{M} & =\text { Kepercayaan merek } \\ \mathrm{Y} & =\text { Keputusan pembelian } \\ \beta_{1}, \beta_{2}, \beta_{3} & =\text { Koefisien dari masing-masing variabel } \\ \mathrm{e}_{1}, \mathrm{e}_{2} & =\text { Error of term atau variabel penganggu }\end{array}$


Untuk mengetahui nilai dari koefisien regresi $(\beta)$ digunakan SPSS. Setelah menghitung koefisien regresi, selanjutnya dapat dihitung nilai error 1 dan error 2 dengan menggunakan rumus sebagai berikut:

$\mathrm{e}_{\mathrm{i}}=\sqrt{\left(1-\mathrm{R}^{2}\right)}$

Keterangan:

$\mathrm{e}_{\mathrm{i}} \quad=$ Error

$\mathrm{R}^{2} \quad=$ Koefisien determinasi

Setelah nilai dari error 1 dan error 2 diketahui, maka selanjutnya dapat dihitung nilai dari koefisien determinasi total dengan rumus sebagai berikut:

$\mathrm{R}^{2} \mathrm{~m}=1-\left(\mathrm{Pe}_{1}\right)^{2}\left(\mathrm{Pe}_{1}\right)^{2}$

Keterangan:

$\mathrm{R}^{2} \mathrm{~m}=$ Koefisien determinasi total

$\mathrm{Pe}_{1} \quad=$ Nilai koefisien error 1

$\mathrm{Pe}_{2}=$ Nilai koefisien error 2

\section{HASIL DAN PEMBAHASAN}

Tabel 2.

Karakteristik Responden

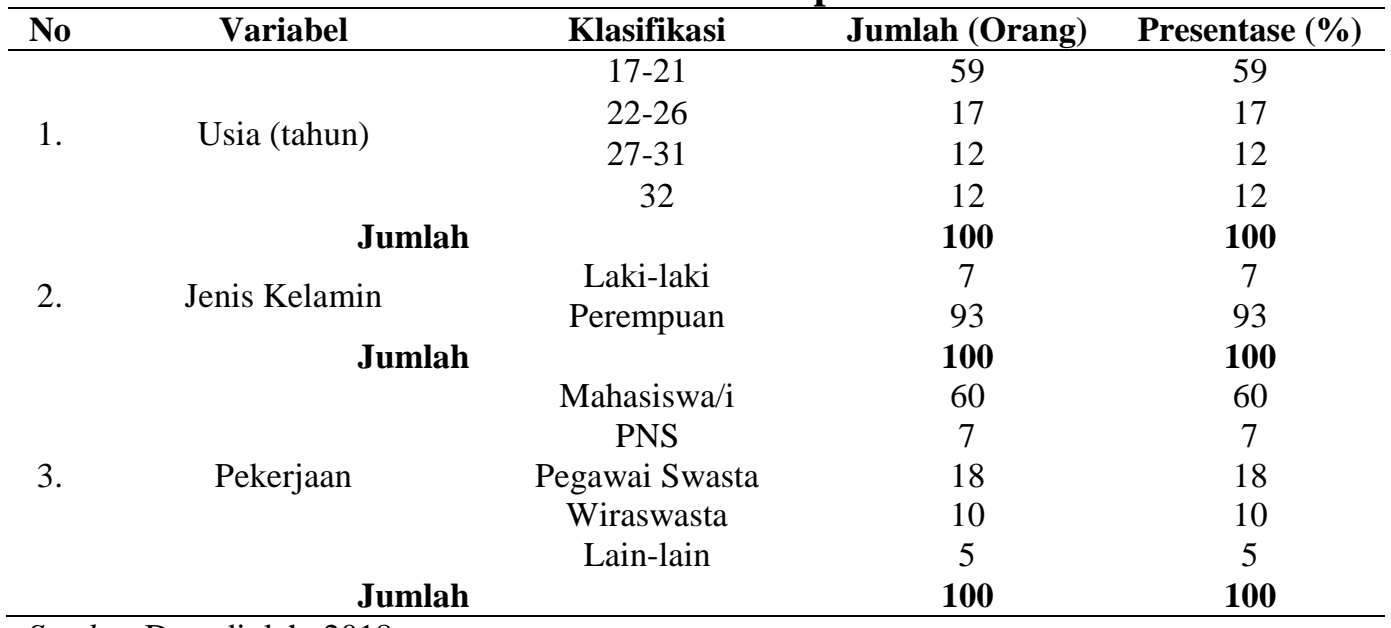

Sumber:Data diolah, 2018 
Jumlah responden dalam penelitian ini adalah 100 orang. Responden yang memberikan tanggapan pada kuesioner dari penelitian ini telah memenuhi kriteriakriteria yang telah ditetapkan dalam kriteria responden penelitian yaitu berdomisili di Kota Denpasar, minimal berpendidikan SMA/SMK/sederajat, dan responden pernah membeli produk Maybelline selama 6 bulan terakhir.

Tabel 2 menunjukkan bahwa variabel usia dengan jumlah responden terbesar berasal dari rentang usia 17 sampai 21 tahun dengan presentase sebesar 59 persen dari total responden yang digunakan, di mana pada rentang usia tersebut seseorang remaja mulai menunjukkan ketertarikannya terhadap make up untuk menunjang penampilannya. Posisi kedua terbesar berada pada rentang usia 22 sampai 26 tahun dengan presentase sebesar 17 persen. Pada rentang usia 27 sampai 31 tahun dan $\geq 32$ menempati posisi ketiga yaitu dengan presentase masing-masing sebesar 12 persen.

Responden dalam penelitian ini didominasi oleh jenis kelamin perempuan yaitu sebesar 93 persen sedangkan sisanya berjenis kelamin laki-laki sebesar 7 persen. Hal ini menunjukkan bahwa perempuan memiliki keputusan pembelian yang lebih tinggi terhadap kosmetik produk Maybelline dibandingkan laki-laki. Dewasa ini kosmetik tidak hanya dapat digunakan oleh para kaum perempuan saja, melainkan kaum laki-laki kini dapat menggunakannnya untuk menunjang penampilannya atau membeli produk kosmetik untuk tuntutan pekerjaan contohnya seperti profesi sebagai Make Up Artist (MUA).

Variabel pekerjaan dalam penelitian ini didominasi oleh mahasiswa/i dengan presentase sebesar 60 persen. Posisi kedua ditempati oleh pegawai swasta 
sebesar 18 persen. Urutan ketiga terbesar yaitu wiraswasta sebesar 10 persen. Selanjutnya diikuti dengan PNS sebesar 7 persen, dan responden yang memiliki pekerjaan lain-lain sebesar 5 persen.

Pada tabel 4 menunjukkan bahwa setiap item pernyataan dari masingmasing variabel pada kuesioner yaitu eWOM, kepercayaan merek, dan keputusan pembelian memiliki nilai $r$-hitung yang lebih besar dari pada $r$ tabel sebesar 0,3 sehingga 10 pernyataan dalam kuisioner yang digunakan dinyatakan valid.

Tabel 4.

Hasil Uji Validitas

\begin{tabular}{ccccc}
\hline No & Variabel & Indikator & $\begin{array}{c}\text { Korelasi Terhadap } \\
\text { Skor Total }\end{array}$ & Keterangan \\
\hline & & $\mathrm{X}_{1}$ & 0,855 & Valid \\
1. & Electronic Word of & $\mathrm{X}_{2}$ & 0,892 & Valid \\
& Mouth (X) & $\mathrm{X}_{3}$ & 0,842 & Valid \\
& & $\mathrm{X}_{4}$ & 0,684 & Valid \\
2. & $\mathrm{X}_{5}$ & 0,821 & Valid \\
& & $\mathrm{M}_{1}$ & 0,926 & Valid \\
3. & $\mathrm{M}_{2}$ & 0,891 & Valid \\
& KepercayaanMerek (M) & $\mathrm{Y}_{1}$ & 0,914 & Valid \\
& & $\mathrm{Y}_{2}$ & 0,921 & Valid \\
\hline
\end{tabular}

Sumber:Data diolah, 2018

Tabel 5.

Hasil Uji Reliabilitas

\begin{tabular}{clcc}
\hline No. & \multicolumn{1}{c}{ VariabelPenelitian } & $\begin{array}{c}\text { Nilai } \text { Apha } \\
\text { Cronbach's }\end{array}$ & Keterangan \\
\hline 1. & Electronic Word of Mouth & 0,878 & Reliabel \\
2. & KepercayaanMerek & 0,782 & Reliabel \\
3. & KeputusanPembelian & 0,900 & Reliabel \\
\hline \multicolumn{2}{l}{ Sumber $:$ Data diolah, 2018 }
\end{tabular}

Uji reliabilitas pada Tabel 5 menyajikan nilai Cronbach's Alpha masingmasing variabel pada kuesioner variabel eWOM sebesar 0,878, kepercayaan merek sebesar 0,782 dan keputusan pembelian sebesar 0,900. Nilai Cronbach's Alpha yang dihasilkan setiap variabel yang digunakan lebih besar dari 0,6 sehingga dapat disimpulkan bahwa kuesioner yang digunakan sudah reliabel. 
Karena kuesioner sudah dinyatakan valid dan reliabel, maka kuesioner dapat digunakan sebagai alat ukur dan analisa lebih lanjut.

Perhitungan koefisien jalur dilakukan dengan menggunakan software SPSS 24.0. Berikut adalah hasil dari analisis jalur persamaan regresi 1.

$$
\begin{aligned}
& \mathrm{M}=1,124+0,756 \mathrm{X} \\
& \mathrm{S}(\beta)=(0,327) \quad(0,079) \\
& \mathrm{t} \quad=(3,435) \quad(9,537) \\
& \text { Sig }=(0,001)(0,000) \\
& R^{2} \quad=0,481 \quad \text { df }=98 \quad F=90,949 \quad \text { Sig }=0,000
\end{aligned}
$$

Berdasarkan hasil analisis jalur struktur 1. maka dapat disusun persamaan struktur 1 adalah sebagai berikut:

$$
\begin{aligned}
& \mathrm{M} \quad=\beta_{1} \mathrm{X}+\varepsilon_{1} \\
& \mathrm{M}=0,694 \mathrm{X} \\
& \varepsilon_{1}\left(\text { error }_{1}\right)=\sqrt{1-\mathrm{R}^{2}} \\
& =\sqrt{1-0,481} \\
& =0,720
\end{aligned}
$$

Berikut adalah hasil dari analisis jalur persamaan regresi 2:

$$
\begin{aligned}
& \mathrm{Y}=0,159+0,686 \mathrm{X}+0.282 \mathrm{M} \\
& \mathrm{S}(\beta)=(0,316) \quad(0,100) \quad(0,092) \\
& \mathrm{t} \quad=(0,505) \quad(6,831) \quad(3,059) \\
& \text { Sig }=(0,615) \quad(0,000) \quad(0,003) \\
& \mathrm{R}^{2} \quad=0,628 \quad \mathrm{df}=97 \quad \mathrm{~F}=81,957 \quad \mathrm{Sig}=0,000
\end{aligned}
$$

Berdasarkan hasil analisis jalur struktur 2, maka dapat disusun persamaan struktur 2 adalah sebagai berikut:

$$
\begin{array}{lll}
\mathrm{Y} & =\beta_{2} \mathrm{X}+\beta_{3} \mathrm{M}+\varepsilon_{2} \\
\mathrm{Y} & =0,587 \mathrm{X}+0,263 \mathrm{M} \\
\varepsilon_{2}\left(\text { error }_{2}\right) & =\sqrt{1-\mathrm{R}^{2}} \ldots \ldots \ldots \ldots
\end{array}
$$




$$
\begin{aligned}
& =\sqrt{1-0,628} \\
& =0,609
\end{aligned}
$$

Berdasarkan hasil analisis $\varepsilon 1$ dan $\varepsilon 2$ maka dapat dihitung koefisien determinasi total adalah sebagai berikut:

$$
\begin{aligned}
\mathrm{R}_{\mathrm{m}}^{2} & =1-\left(\varepsilon_{1}\right)^{2}\left(\varepsilon_{2}\right)^{2} \\
& =1-(0,720)^{2}(0,609)^{2} \\
& =1-(0,518)(0,370) \\
& =0,808
\end{aligned}
$$

Nilai determinasi total sebesar 0,808 mempunyai arti bahwa sebesar 80,8 persen variasi keputusan pembelian dipengaruhi oleh eWOM dan kepercayaan merek, sedangkan sisanya sebesar 19,2 persen dijelaskan oleh faktor lain yang tidak dimasukkan ke dalam model atau penelitian.

Pengaruh variabel electronic word of mouth $(\mathrm{X})$ terhadap kepercayaan merek (M):

$\mathrm{X} \rightarrow \mathrm{M}=\beta_{1}=0,694$

Pengaruh variabel electronic word of mouth (X) terhadap keputusan pembelian (Y):

$X \rightarrow Y=\beta_{2}=0,587$

Pengaruh variabel kepercayaan merek (M) terhadap keputusan pembelian(Y):

$\mathrm{M} \rightarrow \mathrm{Y}=\beta_{3}=0,263$

Pengaruh variabel eWOM (X) terhadap keputusan pembelian (Y) dengan kepercayaan merek (M) sebagai varibel perantara:

$\mathrm{IE}=\mathrm{X} \rightarrow \mathrm{M} \rightarrow \mathrm{Y}=\left(\beta_{1}\right) \mathrm{x}\left(\beta_{3}\right)$

$$
=(0,694 \times 0,263)
$$




$$
=0,183
$$

Total pengaruh variabel eWOM(X) terhadap keputusan pembelian (Y) melalui kepercayaan merek(M) dirumuskan sebagai berikut:

$\mathrm{TE}=\beta_{2}+\left(\beta_{1} \times \beta_{3}\right)$

$$
\begin{aligned}
& =0,587+(0,694 \times 0,263) \\
& =0,769
\end{aligned}
$$

Nilai $F$ sebesar 81,957 dengan nilai probabilitas $($ sig $)=0,000$.Nilai signifikansi sebesar $0,000<0,05$, maka kesimpulannya adalah $\mathrm{H}_{0}$ ditolak dan $\mathrm{H}_{1}$ diterima. Hal ini berarti eWOM dan kepercayaan merekberpengaruh secara simultan dan signifikan terhadap keputusan pembelian.

Nilai $\mathrm{t}=9,537$ dengan nilai probabilitas $(\mathrm{sig})=0,000$.Nilai signifikansi sebesar $0,000<0,05$, maka kesimpulannya adalah $\mathrm{H}_{0}$ ditolak dan $\mathrm{H}_{1}$ diterima.Hal ini berarti eWOM berpengaruh secara positif dan signifikan terhadap kepercayaan merek.

Nilai $\mathrm{t}=6,831$ dengan nilai probabilitas $(\mathrm{sig})=0,000$. Nilai signifikansi sebesar $0,000<0,05$, maka kesimpulannya adalah $\mathrm{H}_{0}$ ditolak dan $\mathrm{H}_{2}$ diterima. Hal ini berarti eWOM berpengaruh secara positif dan signifikan terhadap keputusan pembelian.

Nilai $\mathrm{t}=3,059$ dengan nilai probabilitas $(\mathrm{sig})=0,000$. Nilai signifikansi $0,000<0,05$, maka kesimpulannya adalah $\mathrm{H}_{0}$ ditolak dan $\mathrm{H}_{3}$ diterima. Halini berarti kepercayaan merekberpengaruh secara positif dan signifikan terhadap keputusan pembelian. 
Uji sobel pengaruh electronic word of mouth (X) melalui kepercayaan merek (M) terhadap keputusan pembelian (Y) sebagai berikut:

$$
\begin{aligned}
& S_{a}=\sqrt{b^{2} S_{a}^{2}+a^{2} S_{b}^{2}+S_{a}^{2} S_{b}^{2}} \\
& S_{a b}=\sqrt{0,263^{2} 0,079^{2}+0,694^{2} 0,092^{2}+0,079^{2} 0,092^{2}} \\
& S_{a b}=0,068 \\
& a b=0,694 \times 0,263 \\
& a b=0,183 \\
& \mathrm{Z}=\frac{\mathrm{a}}{\mathrm{S}_{\mathrm{a}}} \\
& \mathrm{Z}=\frac{0,1}{0,0} \\
& Z=2,703
\end{aligned}
$$

Berdasarkan hasil analisis, maka diperoleh nilai Z hitung sebesar 2,703. Nilai Z hitung sebesar 2,703 > Z tabel sebesar 1,96, maka kesimpulannya adalah $\mathrm{H}_{0}$ ditolak dan $\mathrm{H}_{4}$ diterima. Hal ini berartikepercayaan merek signifikan memediasi pengaruh eWOM terhadap keputusan pembelian.

Tujuan yang pertama dari penelitian ini adalah menjelaskan pengaruh eWOM terhadap kepercayaan merek pada konsumen produk Maybelline di Kota Denpasar. Hasil perhitungan menunjukkan tingkat signifikansieWOM sebesar $0,000<0,05$ dengan nilai beta 0,694 , sehingga $\mathrm{H}_{0}$ ditolak dan $\mathrm{H}_{1}$ diterima yaitu eWOM berpengaruh secara positif dan signifikan terhadap kepercayaan merek pada konsumen produk Maybelline di Kota Denpasar.

Hasil penelitian ini sesuai dengan rumusan hipotesis yang menyatakan bahwa eWOM berpengaruh secara positif dan signifikan terhadap kepercayaan 
merek pada konsumen produk Maybelline di Kota Denpasar. Hal ini menunjukkan bahwa semakin sering eWOM dilakukan pada produk Maybelline maka tingkat kepercayaan merek terhadap produk Maybelline juga semakin tinggi. Hasil penelitian ini mendukung penelitian yang dilakukan oleh Twinarutami dan Hermiati (2013), Semuel dan Lianto (2014) dan Anggitasari dan Wijaya (2016)yang menyatakan eWOM berpengaruh positif dan signifikan terhadap kepercayaan merek.

Tujuan yang kedua dari penelitian ini adalah menjelaskan pengaruh eWOM terhadap keputusan pembelian pada konsumen produk Maybelline di Kota Denpasar. Hasil perhitungan menunjukkan tingkat signifikansieWOM sebesar $0,000<0,05$ dengan nilai beta 0,587 , sehingga $\mathrm{H}_{0}$ ditolak dan $\mathrm{H}_{2}$ diterima yaitu eWOM berpengaruh secara positif dan signifikan terhadap keputusan pembelian pada konsumen produk Maybelline di Kota Denpasar.

Hasil penelitian ini sesuai dengan rumusan hipotesis yang menyatakan bahwa eWOM berpengaruh secara positif dan signifikan terhadap keputusan pembelian pada konsumen produk Maybelline di Kota Denpasar. Hal ini menunjukkan bahwa semakin sering eWOM dilakukan pada produk Maybelline maka tingkat keputusan pembelian terhadap produk Maybelline juga semakin meningkat. Hasil penelitian ini mendukung penelitian yang dilakukan oleh Ekawati et al. (2014), Sari et al. (2017) dan Febriasari (2017) yang menyatakan eWOM berpengaruh positif dan signifikan terhadap keputusan pembelian.

Tujuan yang ketiga dari penelitian ini adalah menjelaskan pengaruh kepercayaan merek terhadap keputusan pembelian pada konsumen produk 
Maybelline di Kota Denpasar. Hasil perhitunganmenunjukkan tingkat signifikansikepercayaan merek sebesar $0,003<0,05$ dengan nilai beta 0,263 , sehingga $\mathrm{H}_{0}$ ditolak dan $\mathrm{H}_{3}$ diterima yaitu kepercayaan merek berpengaruh secara positif dan signifikan terhadap keputusan pembelian pada konsumen produk Maybelline di Kota Denpasar.

Hasil penelitian ini sesuai dengan rumusan hipotesis yang menyatakan bahwa kepercayaan merek berpengaruh secara positif dan signifikan terhadap keputusan pembelian pada konsumen produk Maybelline di Kota Denpasar. Hal ini menunjukkan bahwa semakin tinggi kepercayaan merek yang dirasakan konsumen pada produk Maybelline maka tingkat keputusan pembelian terhadap produk Maybelline juga semakin meningkat. Hasil penelitian ini mendukung penelitian yang dilakukan oleh Wilujeng (2014), Khasanah et al. (2017) dan Pratama dan Dwiarta (2017) yang menyatakan kepercayaan merek berpengaruh positif dan signifikan terhadap keputusan pembelian.

Tujuan yang keempat dari penelitian ini adalah menjelaskan peran kepercayaan merek memediasi hubungan eWOM dengan keputusan pembelian pada konsumen produk Maybelline di Kota Denpasar. Hasil perhitungan uji sobel didapatkan dari perbandingan nilai $\mathrm{z}$ hitung sebesar 2,703> z tabel sebesar 1,96, sehingga $\mathrm{H}_{0}$ ditolak dan $\mathrm{H}_{4}$ diterima yaitu kepercayaan merek mampu memediasi pengaruh eWOM terhadap keputusan pembelian pada konsumen produk Maybelline di Kota Denpasar. Besarnya pengaruh tidak langsung kepercayaan merek adalah sebesar 0,183 . Kepercayaan merek memediasi secara parsial, hal ini dibuktikan dengan eWOM berpengaruh signifikan terhadap kepercayaan merek 
signifikan, eWOM berpengaruh signifikan terhadap keputusan pembelian, dan kepercayaan merek berpengaruh signifikan terhadap keputusan pembelian.

Hasil penelitian ini sesuai dengan rumusan hipotesis yang menyatakan bahwa kepercayaan merek signifikan memediasi pengaruh eWOM terhadap keputusan pembelian pada konsumen produk Maybelline di Kota Denpasar. Hal ini menunjukkan bahwa semakin sering eWOM dilakukan pada produk Maybelline maka tingkat kepercayaan merek terhadap produk Maybelline juga semakin tinggi. Apabila kepercayaan merek tersebut tinggi maka secara tidak langsung akan meningkatkan keputusan pembelian terhadap produk Maybelline. Hasil penelitian ini mendukung penelitian yang dilakukan oleh Syafaruddin et al. (2016), Prasad et al. (2017) dan Purnamasari dan Yulianto (2018) yang menyatakan kepercayaan merek signifikan memediasi pengaruh eWOM terhadap keputusan pembelian.

Implikasi pada penelitian dibagi menjadi dua bagian, yaitu implikasi teoretis dan implikasi praktis. Implikasi teoretis adalah hal-hal yang perlu dilakukan peneliti berikutnya dalam rangka mengembangkan hasil penelitian ini, sedangkan implikasi praktis adalah hal-hal yang perlu dilakukan oleh perusahaan Maybelline agar meningkatkan penjualannya. Pada penelitian ini, implikasi teoretis dan praktis dijelaskan secara rinci yaitu sebagai berikut:

Dalam rangka pengembangan produk Maybelline, bagi peneliti berikutnya diharapkan menambah variabel mediasi yaitu brand image yang belum dimasukkan dalam variabel penelitian ini baik yang mempengaruhi eWOM, kepercayaan merek maupun yang mempengaruhi keputusan pembeliann dalam 
produk Maybelline. Pada ukuran sampel sebaiknya ditingkatkan sehingga hasilnya bisa lebih representatif dan bisa digunakan untuk mengeneralisir kondisi yang sesungguhnya terjadi di lapangan.

eWOM secara positif dan signifikan berpengaruh terhadap kepercayaan merek. Konsumen yang telah mengkonsumsi produk Maybelline dan merasakan puas terhadap produk Maybelline maka dengan tulus akan merefensikan produk Maybelline kepada orang lain. Berkembangnya teknologi, kini konsumen berevolusi melakukan WOM dengan cara eWOM yaitu memberikan ulasan dan refensi yang positif mengenai produk Maybelline melalui media elektronik. Efek dari kegiatan eWOM yang positif merupakan salah satu upaya dalam meningkatkan kepercayaan merek produk Maybelline.

eWOM secara positif dan signifikan berpengaruh terhadap keputusan pembelian. Konsumen akan terlebih dahulu mencari informasi mengenai suatu produk sebelum memutuskan untuk melakukan pembelian. Melalui eWOM yang positif konsumen akan terdorong untuk segera melakukan keputusan pembelian terhadap produk Maybelline.

Kepercayaan merek secara positif dan signifikan berpengaruh terhadap keputusan pembelian. Mempertahankan kepercayaan merek memegang peranan yang penting dalam terciptanya keputusan pembelian produk Maybelline karena jika merek Maybelline sudah tidak dipercayai lagi di mata konsumen maka akan sulit untuk berkembang di pasar.

Kepercayaan merek signifikan memediasi secara parsial pengaruh eWOM terhadap keputusan pembelian. Jika eWOM positif sering dilakukan maka akan 
menimbulkan kepercayaan merek di benak konsumen sehingga hal ini akan membuat konsumen semakin yakin melakukan keputusan pembeliannya terhadap produk Maybelline.

\section{SIMPULAN}

eWOM berpengaruh secara positif dan signifikan terhadap kepercayaan merek produk Maybelline. Hasil ini menunjukkan bahwa semakin sering eWOM dilakukan pada produk Maybelline maka tingkat kepercayaan merek terhadap produk Maybelline juga semakin meningkat.

eWOM berpengaruh secara positif dan signifikan terhadap keputusan pembelian pada produk Maybelline. Hal ini menunjukkan bahwa semakin sering eWOM dilakukan pada produk Maybelline maka tingkat keputusan pembelian terhadap produk Maybelline juga semakin meningkat.

Kepercayaan merek berpengaruh secara positif dan signifikan terhadap keputusan pembelian pada produk Maybelline. Hal ini menunjukkan bahwa semakin tinggi kepercayaan merek yang dirasakan konsumen pada produk Maybelline maka tingkat keputusan pembelian terhadap produk Maybelline juga semakin meningkat

Kepercayaan merek signifikan memediasi secara parsial pengaruh eWOM terhadap keputusan pembelian produk Maybelline. Hal ini menunjukkan bahwa eWOM memberikan dampak yang signifikan terhadap keputusan pembelian jika dimediasi oleh kepercayaan merek, yang berarti bahwa keputusan pembelian produk Maybelline sangat tergantung pada bagaimana eWOM yang berlangsung dalam media elektronik. 
Bagi perusahaan Maybelline, hendaknya memperhatikan variabel eWOM yaitu mengatur testimoni atau ulasan yang akan diunggah ke media elektronik dengan memilih celebrity endorser atau konsumen produk Maybelline yang dipercaya untuk memberikan testimoni atau ulasan positif dan memberikan imbalan sebagai gantinya.

Kepercayaan merek yang timbul akibat adanya eWOM, perlu dijaga dengan baik oleh perusahaan Maybelline. Menciptakan produk yang dapat memenuhi kebutuhan dengan menggunakan bahan baku yang aman adalah salah satu cara yang dapat dilakukan oleh perusahaan Maybelline untuk mempertahankan kepercayaan merek produk Maybelline.

eWOM memiliki dampak yang lebih besar terhadap kepercayaan merek. Ketika eWOM positif tercipta maka akan menimbulkan kepercayaan merek di benak konsumen. Ketika konsumen percaya terhadap merek Maybelline, konsumen akan segera melakukan keputusan pembelian produk Maybelline. Hal ini akan menimbulkan peningkatan penjualan terhadap produk Maybelline.

Bagi peneliti selanjutnya diharapkan dapat memperluas ruang lingkup penelitian dengan konsumen yang tersebar di berbagai wilayah, baik skala regional maupun nasional dengan produk yang lebih dikenal masyarakat luas. Penelitian selanjutnya juga dapat mengubah objek penelitiannya. Dalam penelitian di masa mendatang juga perlu dipertimbangkan untuk menggunakan variabel mediasi lain seperti brand image sehingga dapat memperkaya informasi yang diperoleh.

\section{REFERENSI}


Adeliasari., Ivana, V. dan Thio, S. (2014). Electronic Word-of-Mouth (e-WOM) dan Pengaruhnya Terhadap Keputusan Pembelian di Restoran dan Kafe di Surabaya. Jurnal Hospitality dan Manajemen Jasa. 2(2), h: 218-230.

Adiwidjaja, A. J. dan Tarigan, Z. J. H. (2017). Pengaruh Brand Image dan Brand Trust Terhadap Keputusan Pembelian Sepatu Converse. AGORA. 5(3). h: $1-9$.

Akram, M. dan Wibowo, S. (2016). Pengaruh Electronic Word of Mouth Melalui Social Media Instagram Terhadap Keputusan Pembelian Studi Kasus Vespa Piaggio di Kota Bandung. e-Proceeding of Applied Science. 2(3), h: 793-800.

Almana, A. M. dan Mirza, A. A. (2013). The Impact of Electronic Word of Mouth on Consumers' Purchasing Decisions. International Journal of Computer Applications. 82(9), pp: 23-32.

Anggitasari, A. M. dan Wijaya, T. (2016). Pengaruh eWOM Terhadap Brand Image dan Brand Trust, Serta Dampaknya Pada Minat Beli Produk Smartphone Iphone (Studi Pada Masyarakat di Yogyakarta). Jurnal Manajemen Bisnis Indonesia (JMBI). 5(3), h: 266-275.

Arwiedya, M. R. dan Sugiarto, Y. (2011). Analisis Pengaruh Harga, Jenis Media, Promosi Resiko Kinerja, dan Keragaman Produk Terhadap Keputusan Pembelian Via Internet Pada Toko Online (Studi Kasus Pada Konsumen Toko Fashion Online yang Bertindak Sebagai Reseller yang Ada di Indonesia. Jurnal Ekonomi. 1(1), h: 1-28.

Cantallops, A. S. dan Salvi, F. (2014). New consumer behavior: A review of research on eWOM and hotels. International Journal of Hospitality Management. 36(1), pp: 41-51.

Chu, S. C. dan Kim, Y. (2011). Determinants of consumer engagement in electronic word-of-mouth (eWOM) in social networking sites. International Journal of Advertising. 30(1), pp: 47-75.

East, R., Hammond, K. dan Lomax, W. (2008). Measuring the impact of positive and negative word of mouth on brand purchase probability. Journal of Research in Marketing. 25(1), pp: 215-224.

Ekawati, M., Kumadji, S. dan Kusumawati, A. (2014). Pengaruh Electronic Word of Mouth Terhadap Pengetahuan Konsumen serta Dampaknya Pada Keputusan Pembelian (Survei Pada Followers Account Twitter @ WRPdiet). Jurnal Administrasi Bisnis (JAB). 14(2), h: 1-8. 
Elaziz, M. E. A., Khalifa, G. S. A., Aziz, W. M. dan Ma'youf, M. A. A. (2015). Determinants of Electronic Word of Mouth (eWOM) influence on hotel customers' purchasing decision. Journal of Faculty of Tourism and Hotels. 9(2), pp: 194-223.

Febriasari, P. (2017). Pengaruh Traditional Word-Of-Mouth dan Electronic WordOf-Mouth di Internet Terhadap Proses Keputusan Pembelian Laptop Merek Acer Pada Mahasiswa Fakultas Ekonomi. Jurnal Manajemen. 3(4), h: 1-20.

Goyette, I., Ricard, L., Bergeron, J., dan Marticotte, F. (2011). e-WOM Scale: Word-of-Mouth Measurement Scale for e-Services Context. Canadian Journal of Administrative Sciences. 27(1), pp: 5-23.

Guillen, M. J. Y., Aleman, J. L. M. dan Ballester, E. D. (2003). Development and validation of a brand trust scale. International Journal of Market Research. 45(1), pp:35-56.

Jansen, B. J. dan Zhang, M. (2009). Twitter Power: Tweets as Electronic Word of Mouth. Journal of The American Society for Information Science and Technology. 60(11), pp:2169-2188.

Kamtarin, M. (2011). The Effect of Electronic Word of Mouth, Trust and Perceived Value on Behavioral Intention from the Perspective of Consumers. International Journal of Academic Research in Economics and Management Sciences. 1(4), pp: 56-66.

Khasanah, M., Hufron, M. dan Slamet, A. R. (2017). Analisis Pengaruh Harga, Brand Image, Brand Trust dan Atribut Produk Terhadap Keputusan Pembelian Smartphone Samsung (Studi Pada Mahasiswa Universitas Islam Malang). Warta Ekonomi. 7(17), h: 64-77.

Kotler, P. dan Armstrong, G. (2016). Principles of Marketing. Sixteenth Edition. England: Pearson Education, Inc.

Kotler, P. dan Keller, K. L. (2008). Manajemen Pemasaran. Jilid 1. Jakarta:Erlangga.

Kumar, V. (2008). Managing Customers for Profit Strategies to Increase Pofits and Build Loyalty. New Jersey: Wharton School Publishing.

Litvin, S. W., Goldsmith, R. E. dan Pan, B. (2008). Electronic word-of-mouth in hospitality and tourism management. Journal of Tourism Management. 29(3), pp: 458-468. 
Lovelock, C., Wirtz, J. dan Mossry, J. (2011). Pemasaran Jasa. Edisi 7.Jilid 1. Jakarta: Erlangga.

Luk, S. T. K. dan Yip, L. S. C. (2008). The moderator effect of monetary sales promotion on the relationship between brand trust and purchase behaviour. Journal of Brand Management. 15(6), pp:452-464.

Mamahit, P., Soegoto, A. S. dan Tumbuan, W. A. (2015). Pengaruh Brand Image, Brand Trust, dan Kualitas Produk Terhadap Keputusan Pembelian Mobil Toyota All New Yaris Pada PT. Hasjrat Abadi Manado. Jurnal Berkala Ilmiah Efisiensi. 15(5), h:777-787.

Park, D. H. dan Kim, S. (2008). The effects of consumer knowledge on message processing of electronic word-of-mouth via online consumer reviews. Electronic Commerce Research and Applications. 7(4), pp: 399-410.

Pedersen, S. T., Razmerita, L. dan Colleoni, E. (2014). Electronic Word-of-Mouth communication and consumer behaviour: an exploratory study of Danish social media communication influence. LSP Journal. 5(1), pp: 112-131.

Pourabedin, Z. dan Migin, M. W. (2015). Hotel Experience and Positive Electronic Word of Mouth (e-WOM)". International Business Management. 9(4), pp: 596-600.

Prasad, S., Gupta, I. C. dan Totala, N. K. (2017). Social Media Usage, Electronic Word of Mouth and Purchase Decision Involvement. Asia-Pacific Journal of Business Administration. 9(2), pp: 1-30.

Pratama, F. A. dan Dwiarta, I M. B. (2017). Pengaruh Brand Trust dan Kualitas Produk Terhadap Keputusan Pembelian Konsumen Produk Sepeda Motor Honda Beat di Kecamatan Karangpilang, Kota Surabaya. Majalah Ekonomi. 22(1), h: 111-124.

Purnamasari, D. dan Yulianto, E. (2018). Analisis Electronic Word of Mouth Terhadap Keputusan Pembelian Produk Smartphone Oppo Dengan Brand Image dan Brand Rust Sebagai Variabel Moderator (Survei Pada Konsumen Oppo Shop Center Sidoarjo). Jurnal Administrasi Bisnis (JAB). 54(1), h: 92-100.

Sari, N., Saputra, M. dan Husein, J. (2017). Pengaruh Electronic Word of Mouth Terhadap Keputusan Pembelian Pada Toko Online Bukalapak.com. Jurnal Manajemen Magister. 3(1), h: 96-106.

Semuel, H. dan Lianto, A. S. (2014). Analisis eWOM, Brand Image, Brand Trust dan Minat Beli Produk Smartphone di Surabaya. Jurnal Manajemen Pemasaran. 8(2), h: 47-54. 
Sirma, E. (2009). Word-of-mouth marketing from a global perspective. Journal of Marketing and Advertising. 1(1), pp: 1-69.

Suharso, Puguh. (2011). Model Analisis Kuantitatif “TEV”. Jakarta: Indeks.

Suprapti, N. W. S. (2011). Perilaku Konsumen: Pemahaman Dasar dan Aplikasinya dalam Strategi Pemasaran. Denpasar: Udayana University Press.

Syafaruddin, Z., Suharyono, dan Kumadji, S. (2015). Pengaruh Komunikasi Electronicword of Mouth Terhadap Kepercayaan (Trust) dan Niat Beli (Purchase Intention) Serta Dampaknya Pada Keputusan Pembelian (Survey pada Konsumen Online Shopping Zafertech.Com). Jurnal Bisnis dan Manajemen. 3(1), h: 65-72.

Thurau, T. H., Gwinner, K. P., Walsh, G. dan Gremler, D. D. (2004). Electronic Word-of-Mouth Via Customer-Opinion Platforms: What Motivates Consumer to Articulate Themselves on the Internet. Journal of Interactive Marketing. 18(1), pp: 38-52.

Top Brand Award. (2018). Top Brand Index. Diakses dari http://www.topbrandaward.com/top-brand-survey/survey-result/top_brand_index_(2018)_fase_1. Diakses tanggal 23 Maret (2018).

Twinarutami, A. dan Hermiati, T. (2013). Pengaruh Electronic Word Of Mouth (eWOM) terhadap Kepercayaan Merek Pada Media Sosial di Kalangan Mahasiswi (Studi Pada Produk Body Lotion Nivea). Jurnal Administrasi Niaga. h:1-16

Wijaya, T. dan Paramita, E. L. (2014). Pengaruh Electronic Word of Mouth (eWOM) Terhadap Keputusan Pembelian Kamera DSLR. Jurnal Manajemen. 18(3), h: 12-19.

Wilujeng, S. R. (2014). Pengaruh Brand Awareness dan Brand Trust Terhadap Keputusan Pembelian Produk Oriflame. Jurnal Pendidikan Tata Niaga. 2(2).

Wulandari, N. M. R. dan Nurcahya, I K. (2015). Pengaruh Celebrity Endorser, Brand Image, Brand Trust Terhadap Keputusan Pembelian Clear Shampoo di Kota Denpasar. E-Jurnal Manajemen Unud. 4(11), h: 3909-3935.

Xia, L. dan Bechwati, N. N. (2008). Word Of Mouse: The Role Of Cognitive Personalization In Online Consumer Reviews. Journal of Interactive Advertising. 9(1), pp: 3-13. 
Nency Silviana Dewi, PeranKepercayaanMerek..... 